\title{
A Response to Mr. Benn
}

\author{
Amitai Etzioni ${ }^{1}$ \\ Published online: 28 January 2019 \\ (C) Springer Science+Business Media, LLC, part of Springer Nature 2019
}

\begin{abstract}
Etzioni response to Mr. Benn's criticism

Keywords Amitai Etzioni · Communitarianism · "Don’t Vent, Win” · Democracy · Elections · Democrats
\end{abstract}

Frankly, I find it difficult to respond to Mr. Benn. How do you deal with someone who completely mischaracterizes your position and then attacks what you never said? Mr. Benn writes that while all kinds of horrible things are happening in the world ". . . Etzioni is worried about the morality of Trump Administration officials having their dinner interrupted!" Actually, I argued that the disruption of their dinners is unproblematic. What does deserve examination is that the elected officials and public figures of the Democratic Party see much more extreme acts of protest as a valid political strategy. For instance, I quoted Congresswomen Maxine Waters (D-Cal) who, in-effect, is calling for riots. Since then Eric Holder said "When they go low, we kick them. That's what this new Democratic Party is about." If you take it literally it's a call for violence, otherwise what the hell does it mean? I hold that these statements help extend Trump's reign and do nothing to advance progressive changes through the ballot box or on the streets or in any other place.

Those who have no patience for what "he says"; I say these kinds of arguments may want to look at only one simple observation. Mr. Benn claims that because I used the term "win" (re: the elections) I consider politics a game and "This is a typical view of politics for partisans and elites, for whom play and politics, friendly competition and gamesmanship, seem like fitting ways to think about and describe decisions about life, death, and the future of the planet." Actually, we all use the term "win" for many contests other than games, including wars and sports and Nobel prizes and-elections.

Amitai Etzioni

etzioni@gwu.edu

1 The George Washington University, 2100 Pennsylvania Ave, Suite 4058, Washington, DC 20052, United States
Mr. Benn's serious failing is that he confuses my suggestions for the 2018 elections with what ought to be the longterm strategy for major social change. He asks "Yet Etzioni argues that in spite of this history of exclusion, ongoing gerrymandering, voter suppression, and diluting of the Voting Rights Act, 'the ballot box is not only still working but for now is the most promising tool' advocates of social change have." "The key word here is "now"-written on the eve of 2018. I argued that if the Democrats can at least gain control of the House, they will be able to curb significantly the evil Trump spreads. And to win the 2018 elections I suggested it will not serve to antagonize major segments of the Democratic Party and Independents. Nothing is to prevent progressive people from introducing major change while supporting candidates and messages that can win elections.

I wish Mr. Benn had said a bit more about how he sees the major progressive social changes we both favor can best be brought about. Surely it's not by labeling people like me as people who "... reinforces white, male supremacy and implicitly justifies White Rage."

Publisher's Note Springer Nature remains neutral with regard to jurisdictional claims in published maps and institutional affiliations.

Amitai Etzioni is a University Professor and Professor of International Relations at The George Washington University. 